\title{
HOW VALUE NETWORK-BASED CO-INOVATION CONTRIBUTE IN COMPETITIVE ADVANTAGE
}

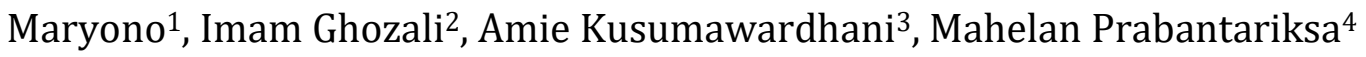 \\ ${ }^{1}$ Faculty of Economics and Business, Diponegoro University \\ ${ }^{2}$ Faculty of Economics and Business, Diponegoro University \\ ${ }^{3}$ Faculty of Economics and Business, Diponegoro University \\ ${ }^{4}$ PT. Bank Tabungan Negara (Persero)
}

\begin{abstract}
This study aims to develop a comprehensive integrated model which helps in explaining the impact of value chain integration's (VCI)'s and relational capability impact on co-innovation in a network and competitive advantage. It also explores the role of value network-based co-innovation as a mediator in the relationship between supply chain integration and competitive advantage, and in the relationship between relational capabilities and competitive advantage of a housing bank sector. The study suggests that firm gains competitive advantage by utilizing value chain integration and relational capability. It is argued here that co-innovation based on value network has mediating role to create competitive advantage. The paper provides a discussion and implication on where value lies and how value is co-created in network of interdependent relationship and illustrate this by sketching a value map in network relationship and possible innovations that can be co-created in housing bank ecosystem. The study involved a single government owned bank located in different cities, therefore the results should be generalized cautiously. This paper constitutes an attempt to stimulate efforts and provide directions on the further conceptual development of value network-based co-innovation (VNBC). The newly developed measure of VNBC and CA exempt from past conceptual streams of the determinant of CA, could be used for valid measurements in future empirical studies in the field of strategic management. The paper provides a practical implications for managers to identify value and utilize new way of analyzing value-chain to create co-innovation within housing bank ecosystem. It also allows manager to practicing relational capability which gives the most impact to competitive advantage.
\end{abstract}

Keywords: Competitive Advantage, value network-based co-innovation, bank ecosystem, relational capability, value chain integration.

\section{INTRODUCTION}

For a long time backlog or gap in provision of affordable housing for low income household was considered the key constraining factor for government to provide housing that meet living standard. The need for housing in Indonesia reach 800.000 unit per years. If the government provides one million houses per year, the need for housing for the whole population will be fulfilled in 17 years, because the backlog that has not been

${ }^{1}$ Corresponding author, Email: maryono1955@gmail.com 
met was 6 million since 2003 (Widoyoko, 2007). In response to a chronic need for homes, Indonesia's government launched the One Million Homes program in mid-2015. According to (Widoyoko, 2007) there are at least two forms of government support the program: firstly by establishing a government -owned company working in housing construction, National Housing Development (Perusahaan Pembangunan Perumahan Nasional, Perumnas). Secondly, the government provided support in the form of a funding institution, by establishing Bank Tabungan Negara (BTN), the state saving bank. This bank is the only one focusing on housing ownership for the low income households. Two thirds of the BTN's lending funds derive from the Ministry of Finance and the Bank of Indonesia at rates well below market levels (Rukmana, 2018).

However, since its inception the programme has been travelling over some rocky roads. Complications in permit and land acquisition has resulted in delays in construction. Red tape and unnecessary government bureaucracy are the main culprits behind this development logjam. Monkkonen (2013) argue that a major constraint to increased development of formal housing is costly property registration and titling. Indonesia has one of the most costly construction permit processes in Asia (Monkkonen, 2013). It became increasingly clear that Perumnas and BTN alone could not maintains role as provider and funding institution of affordable housing on time to reduce backlog, and that this role must necessarily be supported by other players in housing provider ecosystem such as National Land Agency, private sectors developer, state electrical company, and other government infrastructure body (see Figure 1).

BTN should play a central role in one million homes program as an enabler, facilitator and collaborator to encourage housing activities delivered on-time and funded to low income community. The lack of interaction among key stakeholders and the low level of coordination along the housing for the poor provider chain contribute to a situation where housing lending for low income households does not lead to the expected growth.

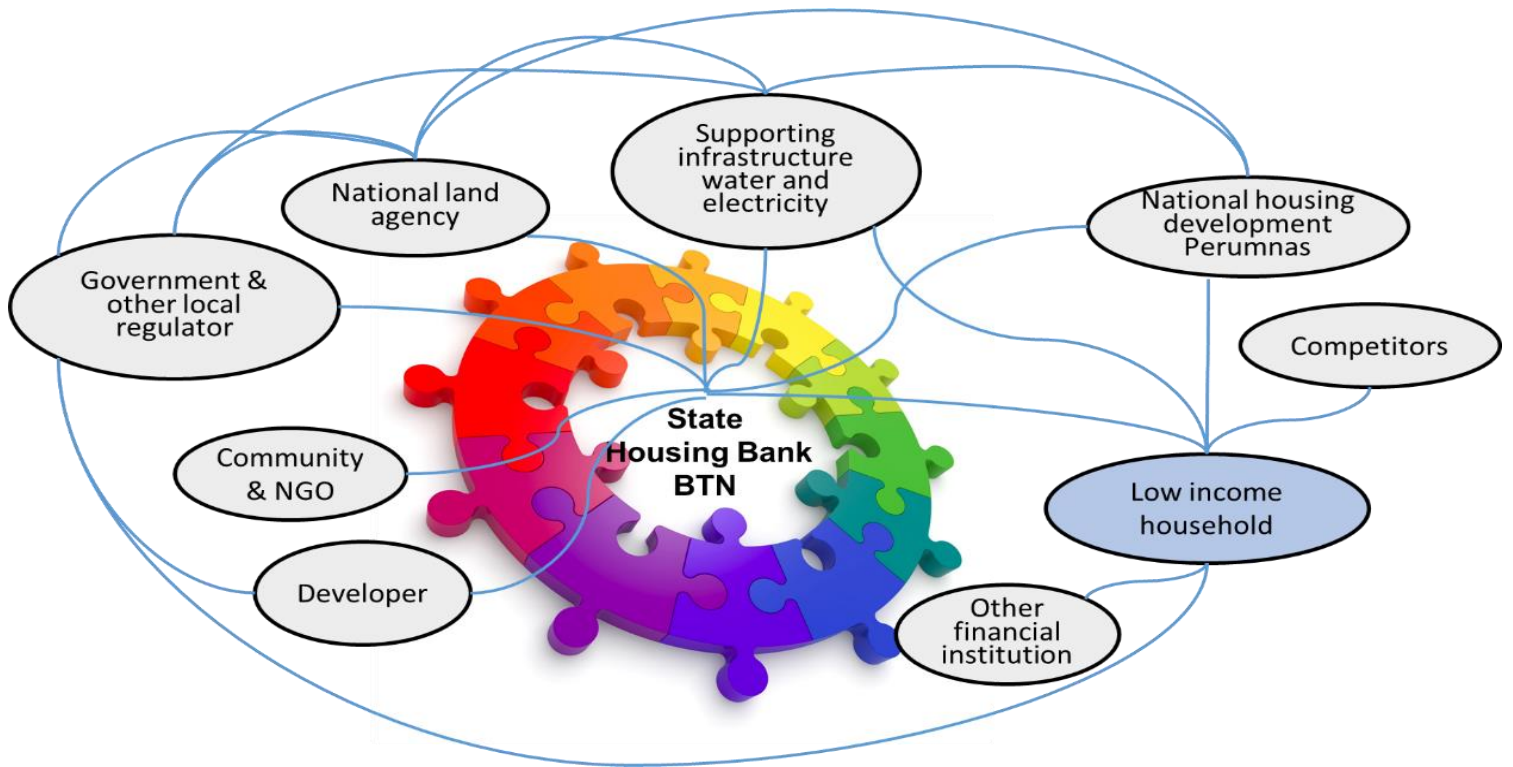

Figure 1. Housing provision ecosystem in Indonesia (Source: Sule, 2017) 


\section{LITERATURE REVIEW}

From value chain to value network to coinnovation

The new ecosystem of business are all networked and interdependent, thus organizations are engaging in new forms of highly collaborative mechanisms and networked structures capable of providing a competitive advantage by combining the best skills or core competencies and resources of two or more organizations (Romero \& Molina, 2011). As a result, the fundamental logic of value creation based-on sequential value chains Porter (1985) is changing into value networks (Mariotti, 2002; Santos, Murmura, \& Bravi, 2018).

Organizations nowadays must continually reintegrate themselves in order to quickly and continually assess their value-network capabilities for a fast response to the rapidly evolving industry dynamics (Fine, Vardan, Pethick, \& El-Hout, 2002; Teece, Peteraf, \& Leih, 2016) and customer's preferences
(Prahalad \& Ramaswamy, 2004). The understanding of a value system is crucial for every organization. Romero and Molina (2011) stated that each product and service offered requires a set of value creation activities that are performed by a number of actors forming a value creating system. Therefore, value creation is no longer considered as a linear function, but a collaborative and co-evolutionary process with partners, allies, suppliers and customers that come together in close relationships within collaborative networks that aggregate knowledge, resources and activities in "value constellations" to co-produce value. In this sense, collaborative networked organizations can provide the basis for agility in dynamic and turbulent market conditions (Borges, Soares, \& Dandolini, 2016; Camarinha-Matos \& Afsarmanesh, 2006). Figure 2. illustrate the co-creation process in the network.

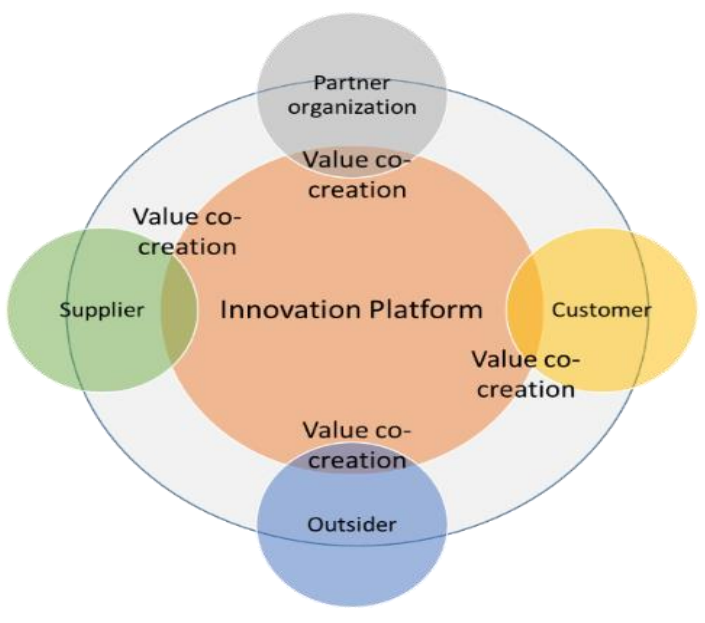

Figure 2. Value chain network (Source: Lee, Olson, \& Trimi, 2012)

A collaborative network, represents "an association of largely autonomous, geographically distributed, and heterogeneous organizations in terms of their: operating environment, culture, social capital, and goals that have come together to collaborate in order to better achieve common or compatibles goals" (Camarinha-Matos \& Afsarmanesh, 2006). Furthermore, a value network is defined as "a virtual relationships 
between two or more organizations that work together to co-create different forms of value such as goods, services, knowledge and revenue" (Allee, 2002; D'Souza, Wortmann, Huitema, \& Velthuijsen, 2015). In this belief, collaborative networks can be seen as value networks in where a group of organisational entities have developed a value co-creation relationships, under a shared belief that they can achieve goals together that would not be possible, or would have higher cost, if attempted individually (MacCarthy \& Jayarathne, 2012; Romero \& Molina, 2011; Salvato, Reuer, \& Battigalli, 2017). Collaboration is especially effective for value creation through new products/services/ ventures, process innovation, and new business models. Collaborative organizations are simultaneously innovative and efficient, agile and scalable (Adler \& Chen, 2011). To facilitate external collaboration, it is imperative that the organization has internal collaboration culture in place. Product design, service-focused innovation, and new venture ideas may require a complex mixture of internal and external collaborationsAccording to Lee et al. (2012) the "shared value" should be the target of any innovation because is directly tied to value creation with other stakeholders such as customers, suppliers, partner organizations, communities, and governments, and it's called "Co-Innovation." The key strategic task in these new collaborative networked is to create an everimproving fit between organizations competencies and customer's needs (Romero \& Molina, 2011), therefore a model based on the platform where internal, external, collaborative, co-creative ideas can be converted to create organizational and shared value is needed (Lee et al., 2012; Peppard \& Rylander, 2006). The model and output of coinnovation platform is illustrated in Figure 3.

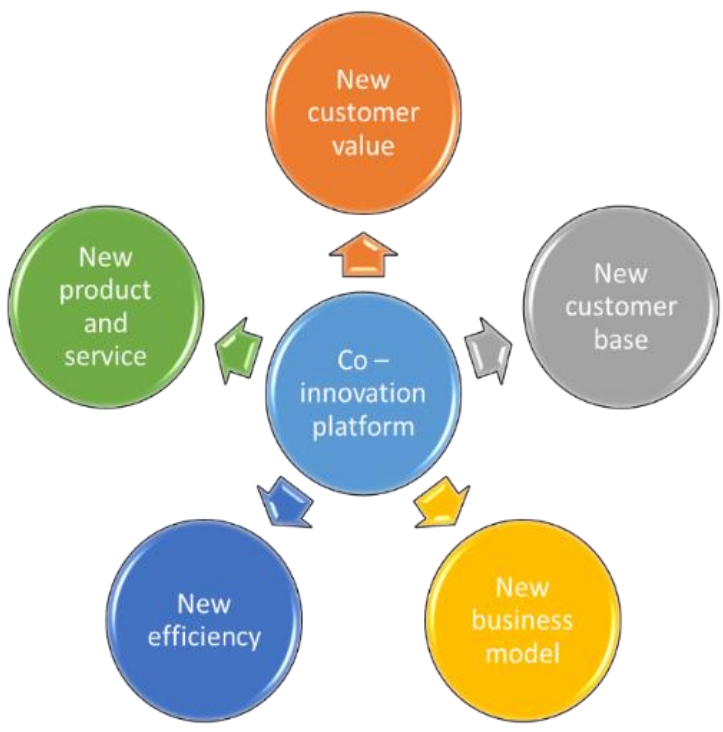

Figure 3. Co-innovation platform and value creation output (Source: Lee et al., 2012)

The key element of innovation is to provide compelling experience with network effects for value creation. Thus, co-innovation is a platform where new ideas or approaches from various internal and external sources are applied differently to create new value or 
experience for all stakeholders, including consumers (Baldwin \& Von Hippel, 2011). The core of co-innovation includes engagement, experience, and co-creation for value that is difficult to imitate by competition.

\section{Relational capability and competitive advantage}

New business models, such as e-business, require ICT expertise of an external partner, banking or financial service firms, and changed internal business structures, all for the shared purpose of stakeholders. Innovation also needs well-coordinated collaborative efforts of internal personnel and external expertise. The study from Pulles, Veldman, and Schiele (2016) say that a company's relational capabilities can be seen as a capacity to expand the company's resource base that can be used by companies to increase competitiveness. Furthermore, the study from Pham, Monkhouse, and Barnes (2017) concluded that relational capability has a positive effect on export performance directly, and moderates the relationship between marketing capabilities and export performance. Obayi, Koh, Oglethorpe, and Ebrahimi (2017) in their study of capabilities between buyers - suppliers concluded that relational capabilities affect operational performance.

The study of Jiang, Mavondo, and Matanda (2015) conclude that relational capabilities have a positive and significant effect on marketing performance and financial performance. Some stream of scholar stated that organizational performance similar to competitive advantage. Pulles et al. (2016) stated that a company's relational capabilities can be seen as a capacity to expand the company's resource that can be used to increase competitiveness. Finally, C.-L. Liu and Lai (2016) in their study of the indirect effect of integrative capability on financial performance concluded that integrative capabilities positively influence resource efficiency, and resource efficiency affects cost competitiveness, in turn cost competitiveness has a positive effect on financial performance, growth and operating profit margin. As such, it is proposed that:

As such, it is proposed that:

P1. Relational capability positively relate to competitive advantage

\section{Relational capability and Co-innovation}

Soosay, Hyland, and Ferrer (2008) state that the capability to work in partnership with other supply chain actors, facilitates radical innovation and incremental innovation. The same thing was stated by Liao and Phan (2016) integrative capabilities (the ability to recognize opportunities, configure and allocate resources) to internet-based organizations have a positive and significant effect on co-innovation. Dvorak (2013) evaluate integrative capabilities and conclude that it influence customer participation in co-innovation through attitude towards cocreation. Han and Li (2015) clarify that relational capability mediates the relationship between intellectual capital and co-innovation performance. So it can be concluded that relational capability directly has a positive effect on co-innovation. Bidar, Watson, and Barros (2016) also supported the relationship by examined the relationship of service capabilities with value co-innovation behavior and concluded that service capabilities have a positive and significant effect on co-innovation. As such, it is proposed that::

$P 2$. Relational capability positively relate to value network-based co-innovation

\section{Value chain integration and Co-innovation}

Research from Ayoub, Abdallah, and Suifan (2017) regarding supplier integration, customer integration and internal integration and its impact on technical co-innovation 
provide significant results from each of the integration dimensions of co-innovation. Then research from Yeniyurt, Henke, and Yalcinkaya (2014) who adopted a supplier perspective and examined the factors that contribute to the desire to engage in coinnovation empirically with longitudinal methods prove that along with increasing time the buyer and supplier relationship will influence the behavior of co-innovation. Furthermore, according to Schreier, Fuchs, and Dahl (2012) the involvement of outsiders (customers) in the innovation process increases the desire to buy because it is mediated by the customer's perceived innovation ability. Similarly, research from Hienerth, Lettl, and Keinz (2014) discusses the synergy between producers, lead users, and user communities empirically proving that user and supplier integration adds value to the innovation process through several synergies. First, shared ecosystem innovation reduces the risk of each actor to start entrepreneurial activities. Both product lines can be extended and create new markets, also known as extension of design space. Third, the interaction of all actors in the ecosystem triggers a self-reinforcing process that creates concern for the creation of process and product innovations. As such, it is proposed that:

$P 3$. Value chain integration positively relate to co-innovation

\section{Value chain integration and competitive advantage}

Most studies in supply chain integration operationalize the variable as multiple dimension (Droge, Vickery, \& Jacobs, 2012; MoyanoFuentes, Sacristán-Díaz, \& Jose MartinezJurado, 2012) only a few studies that conceptualizing supply chain integration as a unidimension (Danese \& Romano, 2012; Liu, Shah, \& Schroeder, 2012). Empirical research of
Talavera (2017) in supply chain integration with operational performance, concluded that supply chain integration and information sharing has a positive and significant effect on supply chain effectiveness and efficiency. The study supports the theory of resource-based view of the firm and the theory of dynamic capability. Supply chain integration has a positive influence on learning in planning and problem solving. Coordination with suppliers in terms of material planning, and with customers in terms of staff planning, also influences tacit and expertise knowledge, whose competitors will be difficult to imitate, therefore organizations will gain a sustainable competitive advantage.

Furthermore, empirical study of Peng, Verghese, Shah, and Schroeder (2013) in external integration and improvement of operating capability and improvement of innovation capabilities, shown 1) a positive relationship between integration with customers and operating improvement capabilities 2) the relationship of integration with customers does not significantly affect the innovation capability of operations. The study from Huo (2012) concluded that customer integration had a significant and positive effect on customeroriented performance. Finally, supply chain integrative capabilities are dynamic capabilities that have a positive effect on sustainable competitive advantage (Vanpoucke, Vereecke, \& Wetzels, 2014). As such, it is proposed that:

$P 4$. Value chain integration positively relate to competitive advantage

\section{Co- innovation and competitive advantage}

An assessment of Löfgren (2014) indicates that co-innovation with customers can enhance competitive advantage in the international market, which results in sustainable success. Several other studies have also proven that innovation and co-innovation in the service process have a positive impact on competitive advantage, for example research from Tsou, Cheng, and Hsu (2015) in co-innovation carried 
out together with business partners to improve processes related to services or services to their customers resulting in a positive effect on competitive advantage, measured by two indicators, namely a) competitive advantage based on a) market and b) employees. Marketbased competitive advantage is demonstrated by differentiation of products and services, while employee-based competitive advantages include unique employee skills and skills.

While research from Jajja, Kannan, Brah, and Hassan (2017) has proven that organizational strategies which able to produce innovations will affect business performance. Tinoco and Ambrose (2017) stated that collaboration with suppliers and customers has a positive effect on innovation carried out together and in turn innovations carried out together will have a positive effect on the organization's business performance. Finally, innovation collaboration with customers has a positive and significant effect on the performance of marketing and customer knowledge management (Fidel,
Schlesinger, \& Cervera, 2015). As such, it is proposed that:

P5. Co-innovation positively relate to competitive advantage

The conceptual model is illustrated in Figure 2.

Based on the conceptual model, that relational capability positively relate to co-innovation and co-innovation positively relate to competitive advantage, therefore we proposed that

P6a. Co-innovation mediate the relationship between value chain integration and competitive advantage

It was put forward that value chain integration positively related to co-innovation and coinnovation positively relate to competitive advantage. As such it is proposed that

$P 6 b$. Co-innovation mediate the relationship between relational capability and competitive advantage

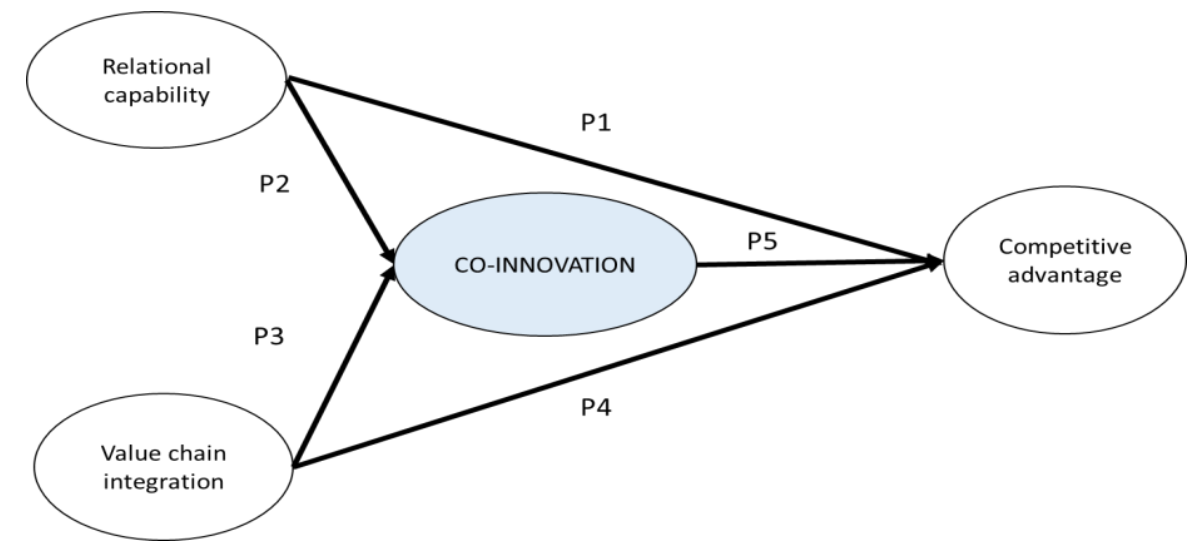

Figure 2. Conceptual Model

\section{Insight for government housing bank}

So what insights can we glean from analyzing the housing bank ecosystem from a network perspective? What is clear is that government housing bank cannot expect to go it alone if they are to provide loan to low income households and as a government agent to take a lead as an integrator to achieve the target of funding to one million home per year. They will be forced to cooperate and partner with a range of low income households, developer, local government to 
national contractor and national land agency. This requires the housing provider network embrace the value network concept and its implications.

Inter-firm relationships facilitate the flow of knowledge and other resources throughout the network. For example, this knowledge can be from customers providing information about their preferences in the terms and interest rate, from contractor that found efficient materials to build homes and way to reduce waste so it will reduce the cost of construction, or from national land agency, perhaps a city or district authority about to launch a new procedure that can cut bureaucracy must faster. This flow of knowledge is crucial for the sustainability of a network. Research has proven that knowledge, capability, network and coinnovation positively relate to competitive advantage, and this will help BTN not only improve their position in competitive nes, but gain sustainable competitive advantage and organizational performance.

\section{RESULTS AND DISCUSSIONS}

During the past decades, research on the topic of value network and co-innovation platform has represented a fruitful area of scholarly inquiry (Abhari, Davidson, \& Xiao, 2017). Yet, the present study represents among the few efforts to examine the mediating role that co-innovation plays in a value network facilitating the competitive advantage resulting from value chain and relational capability of a housing bank for low income household. It has been argued that higher levels of relational capability encourage a firm to more openly innovate with its network, leads to competitive advantage. This paper has also examined the impact of value chain to co-innovation and competitive advantage. It has been argued that value chain impacts the extent to which co-innovation contributes to competitive advantage.

This study contributes to the growing body of literature on co-innovation based and value network by arguing that relational capability and value chain integration is an important determinant of co-innovation. This study also provides new insights into the benefits of network participation when combined with increased levels of coinnovation. State-owned housing bank that enhance their levels of co-innovation in their value network are more likely to gain competitive advantage.

\section{IV.CONCLUSIONS, SUGGESTIONS, AND LIMITATIONS}

In conclusion, this study provides insights into the impact of co-innovation platform on competitive advantage, as well as the role of relational capability and value chain integration in impacting these relationships. Finally, suggestions were offered regarding how firms can best utilize co-innovation with their partners and actor in a networks to maximize the positive impacts of diverse while conserving their limited resources. It is hoped that this paper provides further clarification to the manner in which coinnovation in a value network contributes to the level of competitive advantage.

\section{REFERENCES}

Abhari, K., Davidson, E. J., \& Xiao, B. (2017). Co-innovation platform affordances: developing a conceptual model and measurement instrument. Industrial Management \& Data Systems, 117(5), 873-895. 
Adler, P. S., \& Chen, C. X. (2011). Combining creativity and control: Understanding individual motivation in large-scale collaborative creativity. Accounting, organizations and society, 36(2), 63-85.

Allee, V. (2002). A value network approach for modeling and measuring intangibles. Transparent Enterprise, Madrid. Available at http://www. vernaallee. com.

Ayoub, H. F., Abdallah, A. B., \& Suifan, T. S. (2017). The effect of supply chain integration on technical innovation in Jordan: the mediating role of knowledge management. Benchmarking: An International Journal, 24(3), 594-616.

Baldwin, C., \& Von Hippel, E. (2011). Modeling a paradigm shift: From producer innovation to user and open collaborative innovation. Organization Science, 22(6), 1399-1417.

Bidar, R., Watson, J., \& Barros, A. P. (2016). Literature review to determine environmental and cognitive factors underlying user value cocreation behaviour.

Borges, M. A., Soares, A. L., \& Dandolini, G. A. (2016). Collaborative Networks as Ways to Improve Cross-sector Collaboration in Social Innovation: An Exploratory Study. Paper presented at the Working Conference on Virtual Enterprises.

Camarinha-Matos, L. M., \& Afsarmanesh, H. (2006). Collaborative networks. Paper presented at the International Conference on Programming Languages for Manufacturing.

D’Souza, A., Wortmann, H., Huitema, G., \& Velthuijsen, H. (2015). A business model design framework for viability; a business ecosystem approach. Journal of Business Models, 3(2).

Danese, P., \& Romano, P. (2012). Relationship between downstream integration, performance measurement systems and supply network efficiency. International Journal of Production Research, 50(7), 2002-2013.

Droge, C., Vickery, S. K., \& Jacobs, M. A. (2012). Does supply chain integration mediate the relationships between product/process strategy and service performance? An empirical study. International Journal of Production Economics, 137(2), 250-262.

Dvorak, T. (2013). Co-innovation: Customer motives for participation in co-creation processes via social media platforms.

Fidel, P., Schlesinger, W., \& Cervera, A. (2015). Collaborating to innovate: Effects on customer knowledge management and performance. Journal of business research, 68(7), 14261428.

Fine, C. H., Vardan, R., Pethick, R., \& El-Hout, J. (2002). Rapid-Response capability in value-chain design.(Executive Briefings). MIT Sloan Management Review, 43(2), 23-24. 
Han, Y., \& Li, D. (2015). Effects of intellectual capital on innovative performance: The role of knowledge-based dynamic capability. Management Decision, 53(1), 40-56.

Hienerth, C., Lettl, C., \& Keinz, P. (2014). Synergies among producer firms, lead users, and user communities: The case of the LEGO producer-user ecosystem. Journal of Product Innovation Management, 31(4), 848-866.

Huo, B. (2012). The impact of supply chain integration on company performance: an organizational capability perspective. Supply Chain Management: An International Journal, 17(6), 596-610.

Jajja, M. S. S., Kannan, V. R., Brah, S. A., \& Hassan, S. Z. (2017). Linkages between firm innovation strategy, suppliers, product innovation, and business performance: insights from resource dependence theory. International Journal of Operations \& Production Management, 37(8), 1054-1075.

Jiang, W., Mavondo, F. T., \& Matanda, M. J. (2015). Integrative capability for successful partnering: a critical dynamic capability. Management Decision, 53(6), 1184-1202.

Lee, S. M., Olson, D. L., \& Trimi, S. (2012). Co-innovation: convergenomics, collaboration, and cocreation for organizational values. Management decision, 50(5), 817-831.

Liao, Y.-C., \& Phan, P. H. (2016). Internal capabilities, external structural holes network positions, and knowledge creation. The Journal of Technology Transfer, 41(5), 1148-1167.

Liu, Shah, R., \& Schroeder, R. G. (2012). The relationships among functional integration, mass customisation, and firm performance. International Journal of Production Research, 50(3), 677-690.

Liu, C.-L., \& Lai, P.-Y. (2016). Impact of external integration capabilities of third-party logistics providers on their financial performance. The International Journal of Logistics Management, 27(2), 263-283.

Löfgren, A. (2014). International network management for the purpose of host market expansion: The mediating effect of co-innovation in the networks of SMEs. Journal of International Entrepreneurship, 12(2), 162-182.

MacCarthy, B. L., \& Jayarathne, P. (2012). Sustainable collaborative supply networks in the international clothing industry: a comparative analysis of two retailers. Production Planning \& Control, 23(4), 252-268.

Mariotti, J. L. (2002). The value network. Executive Excellence, 19(7), 18-18.

Monkkonen, P. (2013). Urban land-use regulations and housing markets in developing countries: Evidence from Indonesia on the importance of enforcement. Land Use Policy, $34,255-264$. 
Moyano-Fuentes, J., Sacristán-Díaz, M., \& Jose Martinez-Jurado, P. (2012). Cooperation in the supply chain and lean production adoption: evidence from the Spanish automotive industry. International Journal of Operations \& Production Management, 32(9), 10751096.

Obayi, R., Koh, S., Oglethorpe, D., \& Ebrahimi, S. M. (2017). Improving retail supply flexibility using buyer-supplier relational capabilities. International Journal of Operations \& Production Management, 37(3), 343-362.

Peng, D. X., Verghese, A., Shah, R., \& Schroeder, R. G. (2013). The relationships between external integration and plant improvement and innovation capabilities: the moderation effect of product clockspeed. Journal of Supply Chain Management, 49(3), 3-24.

Peppard, J., \& Rylander, A. (2006). From value chain to value network: Insights for mobile operators. European management journal, 24(2-3), 128-141.

Pham, T. S. H., Monkhouse, L. L., \& Barnes, B. R. (2017). The influence of relational capability and marketing capabilities on the export performance of emerging market firms. International Marketing Review, 34(5), 606-628.

Porter. (1985). The value chain. The Value Chain and Competitive advantage: creating and sustaining superior performance.

Prahalad, C. K., \& Ramaswamy, V. (2004). The future of competition: Co-creating unique value with customers: Harvard Business Press.

Pulles, N. J., Veldman, J., \& Schiele, H. (2016). Winning the competition for supplier resources: The role of preferential resource allocation from suppliers. International Journal of Operations \& Production Management, 36(11), 1458-1481.

Romero, D., \& Molina, A. (2011). Collaborative networked organisations and customer communities: value co-creation and co-innovation in the networking era. Production Planning \& Control, 22(5-6), 447-472.

Rukmana, D. (2018). Upgrading Housing Settlement for the Urban Poor in Indonesia: An Analysis of the Kampung Deret Program. In Metropolitan Governance in Asia and the Pacific Rim (pp. 75-94): Springer.

Salvato, C., Reuer, J. J., \& Battigalli, P. (2017). Cooperation across disciplines: A multilevel perspective on cooperative behavior in governing interfirm relations. Academy of Management Annals, 11(2), 960-1004.

Santos, G., Murmura, F., \& Bravi, L. (2018). Fabrication laboratories: The development of new business models with new digital technologies. Journal of Manufacturing Technology Management, 29(8), 1332-1357. 
Schreier, M., Fuchs, C., \& Dahl, D. W. (2012). The innovation effect of user design: exploring consumers' innovation perceptions of firms selling products designed by users. Journal of Marketing, 76(5), 18-32.

Soosay, C. A., Hyland, P. W., \& Ferrer, M. (2008). Supply chain collaboration: capabilities for continuous innovation. Supply chain management: An international journal, 13(2), 160169.

Talavera, M. G. V. (2017). Supply chain integration and performance: Revisiting the Philippine experience. Philippine Management Review, 24.

Teece, D., Peteraf, M., \& Leih, S. (2016). Dynamic capabilities and organizational agility: Risk, uncertainty, and strategy in the innovation economy. California Management Review, $58(4), 13-35$.

Tinoco, J. K., \& Ambrose, S. C. (2017). Collaborative Customers and Partners: The Ups and Downs of Their Influence on Firm Technology Competence for New Product Development. Journal of Marketing Development \& Competitiveness, 11(4).

Tsou, H.-T., Cheng, C. C., \& Hsu, H.-Y. (2015). Selecting business partner for service delivery coinnovation and competitive advantage. Management Decision, 53(9), 2107-2134.

Vanpoucke, E., Vereecke, A., \& Wetzels, M. (2014). Developing supplier integration capabilities for sustainable competitive advantage: A dynamic capabilities approach. Journal of operations management, 32(7-8), 446-461.

Widoyoko, D. (2007). Good governance and provision of affordable housing in DKI Jakarta, Indonesia. Loughborough: Loughborough University Water, Engineering and Development Centre.

Yeniyurt, S., Henke, J. W., \& Yalcinkaya, G. (2014). A longitudinal analysis of supplier involvement in buyers' new product development: working relations, inter-dependence, coinnovation, and performance outcomes. Journal of the Academy of Marketing Science, 42(3), 291-308. 